\title{
Article
}

\section{Functional Single-Cell Approach to Probing Nitrogen-Fixing Bacteria in Soll Communities by Resonance Raman Spectroscopy with 15N2 Labeling}

Cui, Li, Yang, Kai, Li, Hong-Zhe, Zhang, Han, Su, Jian-Qiang, Paraskevaidi, Maria, Martin, Francis L, Ren, Bin and Zhu, Yong-Guan

Available at https://clok.uclan.ac.uk/22060/

Cui, Li, Yang, Kai, Li, Hong-Zhe, Zhang, Han, Su, Jian-Qiang, Paraskevaidi, Maria, Martin, Francis L orcid iconORCID: 0000-0001-8562-4944, Ren, Bin and Zhu, Yong-Guan (2018) Functional Single-Cell Approach to Probing NitrogenFixing Bacteria in Soil Communities by Resonance Raman Spectroscopy with 15N2 Labeling. Analytical Chemistry, 90 (8). pp. 5082-5089. ISSN 0003-2700

It is advisable to refer to the publisher's version if you intend to cite from the work. http://dx.doi.org/10.1021/acs.analchem.7b05080

For more information about UCLan's research in this area go to http://www.uclan.ac.uk/researchgroups/ and search for < name of research Group>.

For information about Research generally at UCLan please go to http://www.uclan.ac.uk/research/

All outputs in CLoK are protected by Intellectual Property Rights law, including Copyright law. Copyright, IPR and Moral Rights for the works on this site are retained by the individual authors and/or other copyright owners. Terms and conditions for use of this material are defined in the policies page. 


\section{A novel functional single-cell approach to probing}

2 nitrogen-fixing bacteria in soil communities by

\section{3 resonance Raman spectroscopy with ${ }^{15} \mathrm{~N}_{2}$ labelling}

4
TOC/Abstract art

$$
{ }^{15} \mathrm{~N}_{2}
$$

Single-cell resonance Raman- ${ }^{15} N_{2}$ SIP

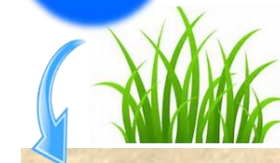

Soil

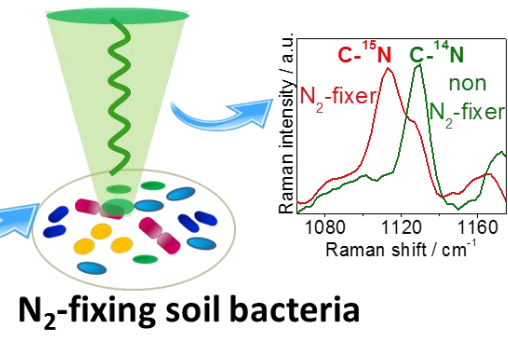




\section{ABSTRACT}

Nitrogen $(\mathrm{N})$ fixation is the conversion of inert nitrogen gas $\left(\mathrm{N}_{2}\right)$ to bioavailable $\mathrm{N}$ essential for all forms of life. $\mathrm{N}_{2}$-fixing microorganisms (diazotrophs), which play a key role in global $\mathrm{N}$ cycling, remain largely obscure because a large majority are uncultured. Direct probing of active diazotrophs in the environment is still a major challenge. Herein, a novel culture-independent single-cell approach combining resonance Raman (RR) spectroscopy with ${ }^{15} \mathrm{~N}_{2}$ stable isotope probing (SIP) was developed to discern $\mathrm{N}_{2}$-fixing bacteria in a complex soil community. Strong RR signals of cytochrome c (Cyt c, frequently present in diverse $\mathrm{N}_{2}$-fixing bacteria), along with a marked ${ }^{15} \mathrm{~N}_{2}$-induced Cyt $\mathrm{c}$ band shift, generated a highly distinguishable biomarker for $\mathrm{N}_{2}$ fixation. ${ }^{15} \mathrm{~N}_{2}$-induced shift was consistent well with ${ }^{15} \mathrm{~N}$ abundance in cell determined by isotope ratio mass spectroscopy. By applying this biomarker and Raman imaging, $\mathrm{N}_{2}$-fixing bacteria in both artificial and complex soil communities were discerned and imaged at the single-cell level. The linear band shift of Cyt c versus ${ }^{15} \mathrm{~N}_{2}$ percentage allowed quantification of $\mathrm{N}_{2}$ fixation extent of diverse soil bacteria. This single-cell approach will advance the exploration of hitherto uncultured diazotrophs in diverse ecosystems.

Keywords: single-cell resonance Raman, $\mathrm{N}_{2}$-fixing bacteria, ${ }^{15} \mathrm{~N}_{2}$ stable isotope probe, cytochrome c, soil community 


\section{INTRODUCTION}

Nitrogen $(\mathrm{N})$ is an essential element sustaining all forms of life on Earth. Biological fixation is a critical process converting inert nitrogen gas $\left(\mathrm{N}_{2}\right)$ to bioavailable $\mathrm{N}$ (ammonia or nitrate) required by all living organisms for biosynthesis. It has been estimated that over half of the fixed $\mathrm{N}$ sustaining the world's population is supplied by biological fixation. ${ }^{1,2}$ This process is exclusively performed by bacteria and archaea (diazotrophs) in free-living form ${ }^{3}$ or in symbiosis with coral, ${ }^{4}$ higher plants, ${ }^{5}$ or animals in different ecosystems. ${ }^{6-9}$ Despite the importance of biological $\mathrm{N}_{2}$ fixation, active diazotrophs along with their distribution in ecosystems, remain largely unknown. ${ }^{10,11}$ One important reason is that a large proportion of diazotrophs remain uncultured to date.

Molecular methods exploiting nitrogenase nifH genes have been widely used to evaluate the potential of $\mathrm{N}_{2}$ fixation in diverse ecosystems in a culture-independent fashion. ${ }^{9,10,12,13}$ Microorganisms expressing nifH genes, including a large portion of uncultured bacteria, were reported to have the genetic potential for $\mathrm{N}_{2}$ fixation. ${ }^{7,10,14}$ However, discordance between presence or transcription of nifH and $\mathrm{N}_{2}$-fixation activity has been revealed, ${ }^{12,13}$ suggesting that species with genetic potential do not necessarily fix $\mathrm{N}_{2}$. Hence, a functional or phenotypic means of identification of $\mathrm{N}_{2}$-fixing microorganisms is urgently needed. Stable isotope probing (SIP) with ${ }^{15} \mathrm{~N}_{2}$ is reported to be the only direct and unambiguous means for identifying $\mathrm{N}_{2}$-fixing bacteria and quantifying biological $\mathrm{N}_{2}$ fixation. ${ }^{15,16}$ Combining ${ }^{15} \mathrm{~N}_{2}$ SIP with single-cell level characterization provides additional advantages of allowing one to bypass the need for culture, whilst imaging of distribution of $\mathrm{N}_{2}$-fixation species in complex communities such as bacteria-protist symbionts. ${ }^{7} \mathrm{~N}_{2}$-SIP combined with high spatial resolution secondary ion mass spectroscopy (SIMS) - especially 
NanoSIMS - is one of the very few available techniques that can probe active $\mathrm{N}_{2}$-fixing bacteria at the single-cell level. ${ }^{6,7,10,12,17,18}$ By applying single-cell NanoSIMS to analyze ${ }^{15} \mathrm{~N}_{2}$-incubated sample, a novel cyanobacterial group actively fixing $\mathrm{N}_{2}$ was discovered in a microbial mat; in contrast, despite expressing genetic potential, a $\mathrm{N}_{2}$-fixing deltaproteobacteria was excluded due to a lack of ${ }^{15} \mathrm{~N}$ enrichment. ${ }^{10,12}$ NanoSIMS imaging of an in vivo ${ }^{15} \mathrm{~N}$-labeled protist inhabiting wood-eating roach revealed $\mathrm{N}_{2}$ fixation in bacterial ectosymbionts of protist. ${ }^{7}$ These applications advance the exploration of uncultured diazotrophs. Nevertheless, SIMS is a destructive approach and thus does not allow important downstream genomic sequencing or even cultivation of active $\mathrm{N}_{2}$-fixing cells.

Raman spectroscopy is an attractive non-destructive method capable of providing information about the chemical bonds of various biomolecules of bacteria and discerning functional bacteria at the single-cell level. ${ }^{19,20}$ For some cells with specific pigments such as cytochrome $\mathrm{c}(\mathrm{Cyt} \mathrm{c})$, carotenoids or chlorophyll, strong resonance Raman (RR) signals can be excited if the laser wavelength is within - or close to - the electronic transition of molecules. ${ }^{21-27}$ Selective enhancement of RR generates a highly characteristic Raman feature of pigment-containing bacteria. Measurement time can also be greatly reduced, facilitating a relatively rapid spectral acquisition such as Raman imaging. Raman imaging is similar to NanoSIMS imaging by providing information regarding the spatial distribution of bacteria in microbial communities. ${ }^{21,23}$ More importantly, in combination with ${ }^{13} \mathrm{C}$ or $\mathrm{D}_{2} \mathrm{O}-\mathrm{SIP}$, single-cell Raman or RR can detect functional or active cells in their natural habitat, based on the Raman shift induced by substitution of 'light' atom in a chemical bond by its 'heavier' isotope. ${ }^{19,28,29}$ Despite these advantages, ${ }^{15} \mathrm{~N}$-induced shifts are far less distinguishable than ${ }^{13} \mathrm{C}$ or ${ }^{2} \mathrm{D}$-induced, and the few reports of single-cell Raman 
with ${ }^{15} \mathrm{~N}$-SIP were all limited to pure-cultured bacteria. ${ }^{19,30}$ Recently, owing to the finding of clear ${ }^{15} \mathrm{~N}$-induced shifts in surface-enhanced Raman spectra (SERS) of bacteria, ${ }^{19,31}$ SERS was successfully applied for bulk analysis of $\mathrm{N}$ assimilation by environmental bacterial community in a wetland. ${ }^{31}$ However, because SERS substrates can easily be contaminated by environmental medium and damaged by laser, single-cell SERS has not been achieved in complex environmental microbial communities. In this regard, normal Raman or RR spectroscopy is more feasible towards investigating environmental bacteria. To date, there is no report using single-cell Raman to study $\mathrm{N}_{2}$-fixing bacteria in complex ecosystems. Identifying an indicative Raman band associated with $\mathrm{N}_{2}$ fixation is the priority for the potential applicability of this approach.

Herein, we showed for the first time that ${ }^{15} \mathrm{~N}_{2}$-induced shifts in the resonance Raman band of Cyt $\mathrm{c}$ are a sensitive and robust indicator of $\mathrm{N}_{2}$-fixation. This biomarker was then used to discern and image the location of $\mathrm{N}_{2}$-fixing bacteria in both artificial and complex soil communities at the single-cell level. The linear band shift versus ${ }^{15} \mathrm{~N}_{2}$ percentages provided a good means to compare $\mathrm{N}_{2}$ fixation extent of diverse soil bacteria. This work provides a novel single-cell resonance Raman approach to discern, image and compare fixation extent of $\mathrm{N}_{2}$-fixing soil bacteria.

\section{MATERIALS AND METHODS}

Strains, media and growth conditions. Four model $\mathrm{N}_{2}$-fixing bacteria, including two free-living Azotobacter sp. (AS1.222) and Azotobacter chroococcum (ACCC10096), two symbiotic Rhizobium radiobacter (ATCC15955) and Bradyrhizobium japonicum (ACCC15067), were purchased from Guangdong Culture Collection Center of Microbiology, China. Azotobacter sp. and A. 
chroococcum were cultured in $\mathrm{N}$-free azotobacter media containing $20 \mathrm{~g} \cdot \mathrm{L}^{-1}$ mannitol, $0.2 \mathrm{~g} \cdot \mathrm{L}^{-1} \mathrm{KH}_{2} \mathrm{PO}_{4}, 0.8 \mathrm{~g} \cdot \mathrm{L}^{-1} \mathrm{~K}_{2} \mathrm{HPO}_{4}, 0.2 \mathrm{~g} \cdot \mathrm{L}^{-1} \mathrm{MgSO}_{4} \cdot 7 \mathrm{H}_{2} \mathrm{O}, 0.1 \mathrm{~g} \cdot \mathrm{L}^{-1}$ $\mathrm{CaSO}_{4} \cdot 2 \mathrm{H}_{2} \mathrm{O}$, and trace amount of $\mathrm{Na}_{2} \mathrm{MoO}_{4} \cdot 2 \mathrm{H}_{2} \mathrm{O}$ and $\mathrm{FeCl}_{3}$ at $28^{\circ} \mathrm{C}$ and $180 \mathrm{rpm}$. $R$. radiobacter and non- $\mathrm{N}_{2}$-fixing strain Shewanella oneidensis MR-1 were grown in Luria Bertani (LB) broth containing $10 \mathrm{~g} \cdot \mathrm{L}^{-1}$ tryptone (Oxoid Ltd., England), $5 \mathrm{~g} \cdot \mathrm{L}^{-1}$ yeast extract (Oxoid Ltd., England), and $10 \mathrm{~g} \cdot \mathrm{L}^{-1} \mathrm{NaCl}$ at $28^{\circ} \mathrm{C}$ and $180 \mathrm{rpm} . B$. japonicum were grown in media containing $1 \mathrm{~g} \cdot \mathrm{L}^{-1}$ yeast exact, $200 \mathrm{~mL}$ of soil extract and $10 \mathrm{~g} \cdot \mathrm{L}^{-1}$ mannitol at $28^{\circ} \mathrm{C}$ and $180 \mathrm{rpm}$. Unless otherwise stated, chemicals were purchased from Sinopharm Chemical Reagent Co., China.

Soil sample collection. Park soil samples were collected from grassland at a depth < $5 \mathrm{~cm}$ in the campus of Institute of Urban Environment, Xiamen, China $\left(24^{\circ} 36^{\prime} 39.90^{\prime \prime} \mathrm{N} 118^{\circ} 03^{\prime} 33.48^{\prime \prime} \mathrm{E}\right)$. The soil samples were homogenized and sieved through a $0.6-\mathrm{mm}$ sieve to remove small stones, grass roots and other debris, then stored at $4^{\circ} \mathrm{C}$ prior to use.

Incubation of model $\mathrm{N}_{2}$-fixing bacteria and soil microcosm with ${ }^{15} \mathrm{~N}_{2}$ gas. An aliquot of $20 \mathrm{~mL} \mathrm{~N}$-free azotobacter media was filled into a 40 -mL crimp-top vial and then inoculated with $20 \mu \mathrm{L}$ of Azotobacter sp. or A. chroococcum after 24-hour culture. Vials were sealed, and air in the headspace was replaced with mixture gas consisting of ${ }^{15} \mathrm{~N}_{2}$ (99 atom\%, purity $>98.5 \%$, Aladdin, China) and oxygen (volume ratio of $\mathrm{N}_{2}$ to $\mathrm{O}_{2}$ is $4: 1$ ) of different volumes to achieve ${ }^{15} \mathrm{~N}_{2}$ of different percentages $\left({ }^{15} \mathrm{~N}_{2} /\left({ }^{15} \mathrm{~N}_{2}+{ }^{14} \mathrm{~N}_{2}\right)\right)$. Considering that ${ }^{15} \mathrm{~N}$ content is $99 \%$ in commercial ${ }^{15} \mathrm{~N}_{2}$ and $0.36 \%$ in natural abundance, ${ }^{32}$ the final ${ }^{15} \mathrm{~N}$ abundance relative to $\mathrm{N}_{2}$ in air in the headspace was $99.36 \%, 49.68 \%, 25.02 \%, 10.22 \%, 0.36 \%$, respectively. Bacteria incubated with different percentages of ${ }^{15} \mathrm{~N}_{2}$ were harvested after culturing for $48 \mathrm{~h}$. Soil microcosm contained $2 \mathrm{~g}$ of park soil in a $12 \mathrm{~mL}$ crimp-top vial. Vials were sealed, purged with 
$\mathrm{O}_{2}$ for 10 min to remove air and then replaced with appropriate volume of ${ }^{15} \mathrm{~N}_{2}$ to achieve $80 \%{ }^{15} \mathrm{~N}_{2}$ and $20 \%$ oxygen in the headspace. The control soil microcosm was supplied with lab air. ${ }^{15} \mathrm{~N}_{2}$-incubated soil microcosm and control were amended with $500 \mathrm{uL}$ of $0.5 \mathrm{M}$ glucose solution and incubated at room temperature (ca. $25^{\circ} \mathrm{C}$ ) under low light conditions for 12 days. All of these incubations were performed in triplicate.

\section{Extracting bacteria from soil microcosms by Nycodenz density gradient} separation. Nycodenz density gradient separation was used to extract bacteria from soil. A modified protocol from a previous report was used. ${ }^{17}$ Briefly, soils post-incubation were homogenized in $10 \mathrm{~mL}$ PBS $\left(\mathrm{NaCl} 8 \mathrm{~g} \cdot \mathrm{L}^{-1}, \mathrm{KCl} 0.2 \mathrm{~g} \cdot \mathrm{L}^{-1}\right.$, $\left.\mathrm{Na}_{2} \mathrm{HPO}_{4} 1.44 \mathrm{~g} \cdot \mathrm{L}^{-1}, \mathrm{KH}_{2} \mathrm{PO}_{4} 0.24 \mathrm{~g} \cdot \mathrm{L}^{-1}\right)$ supplemented with $0.5 \%(\mathrm{v} / \mathrm{v})$ Tween 20 (Aladdin) to detach soil particle-associated cells by vigorously vortexing for $30 \mathrm{~min}$ at room temperature. To separate bacteria from soil particles, 1 vol of the as-prepared soil slurries were introduced into an Eppendorf tube containing 1 vol of Nycodenz ( $\geq 98 \%$, Aladdin) stock solution carefully. Nycodenz stock was prepared by dissolving $8 \mathrm{~g}$ of Nycodenz in $10 \mathrm{~mL}$ sterile water, producing a final density of $1.42 \mathrm{~g} \cdot \mathrm{mL}^{-1}$. This density is proper for efficient capture of soil bacteria and separation from soil particles. ${ }^{17,33}$ The tube was then centrifuged at $14000 \mathrm{~g}$ for 90 $\min$ at $4{ }^{\circ} \mathrm{C}$. The upper and middle aqueous layers containing bacteria were collected and mixed with 10 vol PBS in a fresh centrifuge tube. The bacteria inside were then collected by centrifuging at $5000 \mathrm{rpm}$ for $10 \mathrm{~min}$ and washed with ultrapure water twice for further Raman analysis.

Single-cell Raman measurement and Raman mapping acquisition. To prepare bacteria for single-cell Raman measurements, bacterial solution from model strains or soil samples were washed twice by DI water by centrifuging at $5000 \mathrm{rpm}$ for 3 
min and then adjusting to a proper concentration in order to obtain single-cell dispersion on aluminum (Al) foil substrate. ${ }^{34}$ An aliquot of $2 \mu \mathrm{L}$ of the as-prepared bacteria were loaded on $\mathrm{Al}$ foil and air-dried at room temperature. To construct an artificial community consisting of Azotobacter sp. and $S$. oneidensis, one bacterial solution was applied to the $\mathrm{Al}$ foil and allowed to air-dry whereupon the second was applied to the same spot and also allowed to dry. Single-cell Raman spectra and Raman mapping were obtained using a LabRAM Aramis (HORIBA Jobin-Yvon) confocal micro-Raman system equipped with a $600 \mathrm{~g} / \mathrm{mm}$ grating. Excitation was provided by a 532-nm Nd: YAG laser. A 100x dry objective with a numerical aperture of 0.9 (Olympus) was employed. For single-cell Raman measurements, acquisition time was $5 \mathrm{~s}$ and 25 spectra were acquired from each bacterial sample. Raman mapping was employed to generate Raman images of artificial communities and also soil bacterial community containing $\mathrm{N}_{2}$-fixing bacteria. The step-size was set at $1.5 \mu \mathrm{m}$ in a rectangular mapping area with acquisition time of $2 \mathrm{~s}$ on each point.

Raman spectral and mapping data analysis. LabSpec5 software (HORIBA Jobin-Yvon) was used to process single-cell Raman spectra. After spectral extraction and baseline subtraction (polynomial, degree 6), mean spectra from each sample were calculated. The overlapped $1114\left(\mathrm{C}-{ }^{15} \mathrm{~N}\right)$ and $1129 \mathrm{~cm}^{-1}\left(\mathrm{C}-{ }^{14} \mathrm{~N}\right)$ bands were deconvoluted using the GaussLorenz peak fitting function and the resulting peak area was used to calculate the intensity ratio of these two bands. Principal component analysis (PCA) and the required spectral pre-processing were performed using IRootLab toolbox (https://code.google.com/p/irootlab/) running on MATLAB 2012a. ${ }^{35,36}$ Spectral pre-processing included spectral extraction (from 1095 to 1145 $\mathrm{cm}^{-1}$ ), rubberband subtraction and vector normalization. PCA was then performed by 
reducing spectral variables to 10 factors accounting for more than $99 \%$ of the total variance. The resulting PCA 1-D (PC1) scores were plotted against ${ }^{15} \mathrm{~N}_{2}$ percentages. OriginPro8.5 was used to perform statistical calculation of average value \pm standard deviation and linear regression fitting. One-way ANOVA with Tukey's Multiple comparison test was conducted in GraphPad Prism 5 for significance analysis of ${ }^{15} \mathrm{~N}$-induced Raman band change; $P<0.05$ was considered significant. Direct classical least square (DCLS) modelling in Labspec 5 was employed to construct a Raman image of $\mathrm{N}_{2}$-fixing and non- $\mathrm{N}_{2}$-fixing bacteria based on multidimensional Raman mapping data matrix. $\mathrm{C}_{-}{ }^{15} \mathrm{~N}$ band at $1114 \mathrm{~cm}^{-1}$ and $\mathrm{C}_{-}{ }^{14} \mathrm{~N}$ at $1129 \mathrm{~cm}^{-1}$ were selected as the model, and then DCLS operation finding the linear combination of model spectra that matched most closely the original data was applied to all traces of the original data sets to construct Raman image of each component.

\section{Quantification of ${ }^{15} \mathrm{~N}$ incorporation in $\mathrm{N}_{2}$-fixing bacteria by isotope ratio mass} spectroscopy (IRMS). To measure the bulk isotope composition $\left({ }^{15} \mathrm{~N} \%\right)$ of $\mathrm{N}_{2}$-fixing bacteria incubated with different percentages of ${ }^{15} \mathrm{~N}_{2}$ to natural $\mathrm{N}_{2}$ in air, 0.01-0.05 mg (dry weight) of ${ }^{15} \mathrm{~N}$-labeled lyophilized bacteria and 0.15-0.18 mg of urea was placed in a tin capsule. For non labeled $\mathrm{N}_{2}$-fixing bacteria, $1 \mathrm{mg}$ of lyophilized cell powder was put in a tin capsule. Urea of $0.30-0.34 \mathrm{mg}$ was used as standard. Samples were analyzed with an elemental analyzer (Flash HT 2000 Thermo Fisher) coupled via a ConFlo IV device to the IRMS (Delta V advantage). Isotope composition was calculated using the equation below:

$\mathrm{At}^{15} \mathrm{~N} \%=\left(\mathrm{M}_{\text {urea }} \times 46.67 \% \times 0.367 \%+\mathrm{M}_{\text {bacteria }} \times 9.77 \% \times{ }^{15} \mathrm{~N} \%\right) /\left(\mathrm{M}_{\text {urea }} \times 46.67 \%+\mathrm{M}_{\text {bacteria }} \times\right.$ $9.77 \%$ ), where $\mathrm{At}^{15} \mathrm{~N} \%$ is the percentage of ${ }^{15} \mathrm{~N}$ in total $\mathrm{N}$ and can be measured by IRMS, $\mathrm{M}_{\text {urea }}$ and $\mathrm{M}_{\mathrm{bacteria}}$ are the weight of urea and bacteria in tin capsule, $0.367 \%$ is the natural abundance of ${ }^{15} \mathrm{~N}$ in urea, $46.67 \%$ and $9.77 \%$ are the total nitrogen 
content in urea and bacteria respectively, ${ }^{15} \mathrm{~N} \%$ is the abundance of ${ }^{15} \mathrm{~N}$ in bacteria that will be calculated.

\section{RESULTS AND DISCUSSION}

\section{Resonance Raman spectra of cytochrome $c$ is a common signal in diverse}

\section{$\mathbf{N}_{2}$-fixing bacteria.}

To identify a common Raman signal in diverse $\mathrm{N}_{2}$-fixing bacteria, we examined four model $\mathrm{N}_{2}$-fixing bacteria including two rhizobium-originated (B. Japonicum and $R$. radiobacter) and two free-living (Azotobacter sp. and A. chroococcum), and five environmental $\mathrm{N}_{2}$ fixers isolated from soil by plating soil slurry onto $\mathrm{N}$-free agar plates. Only $\mathrm{N}_{2}$-fixing bacteria can form colonies on these agar plates since atmospheric $\mathrm{N}_{2}$ provided the sole nitrogen source required for their growth. These soil $\mathrm{N}_{2}$-fixing isolates were affiliated to the genera of Azotobacter, Rhizobium and Raoultella based on 16S rRNA sequencing and phylogenetic analysis (Figure S1a). These genera were reported to be from $\mathrm{N}_{2}$-fixer group. ${ }^{9,37}$ To further confirm $\mathrm{N}_{2}$ fixation potential of these strains, Dinitrogenase reductase genes (nifH), which are the most widely used marker gene to identity $\mathrm{N}_{2}$-fixing bacteria, were amplified and visualized on agarose gel. All the model and soil $\mathrm{N}_{2}$-fixer isolates displayed a band specific to nifH genes, which, however, are absent in non $\mathrm{N}_{2}$-fixing $S$. oneidensis, E.coli and non-templated control (Figure 1a). Phylogenetic analysis of nifH amplicons further supported that these five soil isolates were $\mathrm{N}_{2}$ fixers (Figure $\mathrm{S} 1 \mathrm{~b}$ ).

Single-cell Raman spectra were acquired from four model $\mathrm{N}_{2}$-fixing bacteria and all colonies (approximately 32) formed by $\mathrm{N}_{2}$-fixing soil bacteria (Figure 1b). It is interesting to find that all of them display characteristic Raman bands of Cyt $\mathrm{c}$ at 749 $\mathrm{cm}^{-1}$ (pyrrole breathing mode), $1129[\mathrm{v}(\mathrm{C}-\mathrm{N})], 1312[\delta(\mathrm{C}-\mathrm{H})]$, and $1589 \mathrm{~cm}^{-1}$ $[v(C-C)]$, which are almost the same as that of pure Cyt c. ${ }^{21,38,39}$ Strong Cyt c signal 
245 was also recently reported in symbiotic rhizobia isolated from legumes nodules. ${ }^{40}$

246 These observations demonstrate that Cyt $\mathrm{c}$ is commonly present in both free-living 247 and symbiotic $\mathrm{N}_{2}$-fixing bacteria of either model or environmental strains. The 248 existence of Cyt $\mathrm{c}$ in diazotrophs is associated with the crucial role of Cyt $\mathrm{c}$ in 249 protecting respiration as a terminal oxidase by rapid consumption of $\mathrm{O}_{2}$ affecting the 250 activity of $\mathrm{O}_{2}$-labile nitrogenase. ${ }^{41}$ In addition, intensities of Cyt c relative to Amide 251 I at $1664 \mathrm{~cm}^{-1}$ were found to fluctuate in these $\mathrm{N}_{2}$-fixer. Both the physiological state 252 of bacteria and the redox state of Cyt c were reported to affect Cyt c intensity. For 253 instance, significantly higher Cyt c signal was observed in Rhizobium 254 leguminosarum bv. viciae isolated from nodules than those grown in culture; ${ }^{40}$ 255 reduced state of Cyt $\mathrm{c}$ generated more intense signal than the oxidized state due to 256 shift in electronic transition. ${ }^{23}$ In addition, Raman signal of Cyt $\mathrm{c}$ is much stronger 257 than that of other intracellular bacterial constituents, such as bands at $1002 \mathrm{~cm}^{-1}$ 258 (phenylalanine), $1240 \mathrm{~cm}^{-1}$ (protein), $1450 \mathrm{~cm}^{-1}$ (lipid) and $1664 \mathrm{~cm}^{-1}$ (protein), 259 despite their higher abundance. Cyt $\mathrm{c}$ is a hemeprotein showing maximum electronic 260 absorption at around $550 \mathrm{~nm},{ }^{42}$ matching well with the $532 \mathrm{~nm}$ laser and thus 261 generating a selective resonance Raman enhancement.

262 Not only $\mathrm{N}_{2}$-fixing bacteria show Cyt c RR peaks, RR signals of Cyt c have also 263 been reported in nitrifier bacteria, annamonx bacteria, and electron-generating 264 bacteria such as S. oneidensis (Figure 1b) and Geobacter. ${ }^{21,23}$ Therefore, despite the 265 fact that the strong and characteristic Raman signal of Cyt c makes it highly 266 distinguishable, it is insufficient to identify $\mathrm{N}_{2}$-fixing bacteria because Cyt $\mathrm{c}$ is also 267 present in other bacteria that are unable to fix nitrogen. Among the four RR bands of 268 Cyt c, the band at $1129 \mathrm{~cm}^{-1}$ was assigned to $\mathrm{C}-\mathrm{N}$ stretch, providing a good potential 
target to incorporate ${ }^{15} \mathrm{~N}_{2}$ stable isotope into C-N. The resulting Raman shift would then provide additional evidence for $\mathrm{N}_{2}$ fixation.

\section{${ }^{15} \mathrm{~N}_{2}$-induced Raman shifts in cytochrome $c$ are a biomarker of $\mathrm{N}_{2}$-fixing} bacteria

To test this hypothesis, we incubated Azotobacter sp. and A. chroococcum in $\mathrm{N}$-free medium with different percentages of ${ }^{15} \mathrm{~N}_{2}$ relative to $\mathrm{N}_{2}$ in air, i.e., $99.36 \%$, $49.68 \%, 25.02 \%, 10.22 \%$ and $0.36 \%\left({ }^{15} \mathrm{~N}\right.$ natural abundance). Mean single-cell Raman spectra from approximately 25 individual cells under each ${ }^{15} \mathrm{~N}_{2}$ incubation conditions are shown in Figure $2 \mathrm{a}$ and $2 \mathrm{~b}$. It is notable to observe that the $1129 \mathrm{~cm}^{-1}$ band (C-N stretch) at $0.36 \%{ }^{15} \mathrm{~N}_{2}$ shifted markedly to $1114 \mathrm{~cm}^{-1}$ at $99.36 \%{ }^{15} \mathrm{~N}_{2}$. The around $15 \mathrm{~cm}^{-1}$ shift is very close to that the $13 \mathrm{~cm}^{-1}$ shift observed in ${ }^{15} \mathrm{~N}$ isotopically labeled pure Cyt $\mathrm{c},{ }^{43}$ confirming that it is the substitution of light ${ }^{14} \mathrm{~N}$ with heavier ${ }^{15} \mathrm{~N}$ in the $\mathrm{C}-\mathrm{N}$ bond resulting in a decrease of vibrational frequency of C-N stretch. By comparison, no obvious shifts were observed in other Cyt c bands wherein $\mathrm{N}$ was absent: $749 \mathrm{~cm}^{-1}$ (ring breathing), $1312 \mathrm{~cm}^{-1}(\mathrm{C}-\mathrm{H}), 1589 \mathrm{~cm}^{-1}$ (C-C), or bacterial composition-related bands. Figure $2 \mathrm{~b}$ shows the enlarged spectra including exclusively 1114 and $1129 \mathrm{~cm}^{-1}$ bands. With increasing ${ }^{15} \mathrm{~N}_{2}$, the 1129 $\mathrm{cm}^{-1}$ band $\left(\mathrm{C}-^{14} \mathrm{~N}\right)$ decreased whilst the $1114 \mathrm{~cm}^{-1}$ band $\left(\mathrm{C}_{-}{ }^{15} \mathrm{~N}\right)$ increased. The co-existence of $1129 \mathrm{~cm}^{-1}$ and $1114 \mathrm{~cm}^{-1}$ in individual bacteria indicates that only a proportion of $\mathrm{N}$ in intracellular Cyt $\mathrm{c}$ is replaced by the heavier ${ }^{15} \mathrm{~N}$.

By deconvoluting these two bands using peak fitting in Labspec software (Figure $\mathrm{S} 2$ ), peak area ratio of $1114 \mathrm{~cm}^{-1}$ band against the sum of peak area of $1114 \mathrm{~cm}^{-1}$ and $1129 \mathrm{~cm}^{-1}$ bands $\left(\right.$ Area $_{1114} /\left(\right.$ Area $_{1114}+$ Area $\left.\left._{1129}\right)\right)$ from individual spectrum were plotted against ${ }^{15} \mathrm{~N}_{2}$ percentages. A linear relationship with $R^{2}$ of 0.968 was obtained. 
To achieve a rapid analysis of large numbers of spectra from single cells and avoid possible errors in deconvolution of overlapped spectra, PCA was also performed on spectral profile between 1095 and $1145 \mathrm{~cm}^{-1}$ (Figure 2c). Scores along PC1, accounting for $87.5 \%$ of variance, generated an even better linear relationship with ${ }^{15} \mathrm{~N}_{2}$ percentages $\left(R^{2}=0.998\right)$ than the peak area ratio $\left(R^{2}=0.968\right)$.

To validate Raman results of $\mathrm{N}_{2}$ fixation, bulk isotope analysis by isotope ratio mass spectroscopy was used to quantify how much $\mathrm{N}$ was fixed in bacteria. The abundance of ${ }^{15} \mathrm{~N}$ in bacteria was determined to be $0.36 \%$ (close to natural abundance of $\left.{ }^{15} \mathrm{~N}\right), 5.89 \%, 15.01 \%, 29.97 \%$, and $66.16 \%$, and linearly increased with percentage of atmospheric incubation ${ }^{15} \mathrm{~N}_{2}$ (Figure 2d), whereas non- $\mathrm{N}_{2}$ fixer $S$. oneidenis containing Cyt $\mathrm{c}$ and $E$. coli only displayed ${ }^{15} \mathrm{~N}$ of natural abundance. This measurement fully demonstrated that bacteria had incorporated ${ }^{15} \mathrm{~N}$ and a higher ${ }^{15} \mathrm{~N}_{2}$ percentage resulted in a higher incorporation extent and Raman shift. A further correlation analysis indicated that ${ }^{15} \mathrm{~N}$ content of bacteria corresponded linearly to PC1 scores (Figure 2e), providing a way to measure the extent of $\mathrm{N}_{2}$ fixation by RR spectral profile of Cyt c at single-cell level, protist. ${ }^{16,44,45}{ }^{15} \mathrm{~N}$ abundance in bacteria was around three-fifth of the ${ }^{15} \mathrm{~N}_{2}$ percentage, indicating that $\mathrm{N}_{2}$ fixers were not fully labeled by ${ }^{15} \mathrm{~N}$, consistent with Raman result that both 1114 and $1129 \mathrm{~cm}^{-1}$ bands were observed. Detection limit of Raman- ${ }^{15} \mathrm{~N}_{2}$ SIP was defined as the minimum ${ }^{15} \mathrm{~N}_{2}$ that can induce significant spectral change. Spectral change was analyzed by PCA and the resulting PC1 scores were used for significance analysis of ${ }^{15} \mathrm{~N}$-induced spectral change via one-way ANOVA. Detection limit was determined to be $10.22 \%$ ${ }^{15} \mathrm{~N}_{2}$, corresponding to $5.89 \%{ }^{15} \mathrm{~N}$ abundance in bacteria, at which spectra were significantly different from that in air (one-way ANOVA, $P<0.05$ ). The linear band shifts were also obtained in A. chroococcum (Figure S3) with similar slope and 
intercept $(y=0.098 x-0.5059)$ to that of Azotobacter sp. $(y=0.091 x-0.5411)$ based on PC1 scores.

Bacteria without Cyt c like E. coli display peaks at around $1123 \mathrm{~cm}^{-1}$ (carbohydrate), which is close to $\mathrm{C}^{14} \mathrm{~N}$ and $\mathrm{C}-{ }^{15} \mathrm{~N}$ at 1129 and $1114 \mathrm{~cm}^{-1}$ (Figure S4), but much lower, thus will not interfere ${ }^{15} \mathrm{~N}$-induced shift. Bacteria containing carotenoid show strong RR signal at 1155 and $1511 \mathrm{~cm}^{-1}$. Although the band at 1155 $\mathrm{cm}^{-1}$ has some overlap with $\mathrm{C}_{-}{ }^{14} \mathrm{~N}$ band of $\mathrm{Cyt} \mathrm{c}$ at $1129 \mathrm{~cm}^{-1}$, it separates well with $\mathrm{C}-{ }^{15} \mathrm{~N}$ band at $1114 \mathrm{~cm}^{-1}$, thus exerting no effect on identification of ${ }^{15} \mathrm{~N}_{2}$ fixation. Cyanobacteria can also fix $\mathrm{N}_{2},{ }^{12}$ however, its fluorescence was too strong to observe Raman signal (Figure S5), so RR combined with ${ }^{15} \mathrm{~N}_{2}$ is not enough to detect cyanobacteria as $\mathrm{N}_{2}$ fixers. The further application of SERS with ${ }^{15} \mathrm{~N}_{2}$ excited with a laser out of fluorescence can provide a solution.

The above observations indicate that the marked ${ }^{15} \mathrm{~N}_{2}$-induced shift in $\mathrm{C}-\mathrm{N}$ bond of Cyt $\mathrm{c}$ is a sensitive and highly distinguishable biomarker for $\mathrm{N}_{2}$-fixing bacteria. The linear shift also provides a good means towards evaluating $\mathrm{N}_{2}$-fixing extent in a quantitative manner.

\section{Probing and Raman imaging of $\mathbf{N}_{2}$-fixing bacteria in artificial communities}

Important advantages of single-cell measurements lie in the ability to discern and image $\mathrm{N}_{2}$-fixing bacteria in a complex community. Herein, an artificial community comprising S. oneidensis and ${ }^{15} \mathrm{~N}_{2}$-incubated Azotobacter sp. was constructed. Both species contain Cyt c, while only Azotobacter sp. can fix nitrogen. Raman imaging was used to discern and locate ${ }^{15} \mathrm{~N}_{2}$-fixing Azotobacter sp. in this artificial community. 
Figure $3 \mathrm{a}$ shows a photomicrograph of such an artificial community with

Azotobacter sp. appearing as spherical and S. oneidensis as rod-shaped. Because of their highly distinguishable shapes, the distribution of the two species is visually relatively clear except when clumped on top of each other. By using the $1114 \mathrm{~cm}^{-1}$ and $1129 \mathrm{~cm}^{-1}$ bands characteristic of ${ }^{15} \mathrm{~N}$-labeled $\mathrm{N}_{2}$-fixing Azotobacter sp. and $S$. oneidensis $\left({ }^{14} \mathrm{~N}\right)$ respectively (Figure $3 \mathrm{c}$ ), Raman imaging was acquired and pseudo-color Raman image was generated (Figure 3b). Red regions were identified as Azotobacter sp. whilst green regions as S. oneidensis. The distribution of both bacterial species in Raman images is consistent with the conventional photomicrographs. For example, the encircled spherical Azotobacter sp. in the photomicrograph can be found in the same place as that shown in red in the corresponding Raman image, as is the case for $S$. oneidensis. This result demonstrates the accuracy of Raman imaging in indicating the site of $\mathrm{N}_{2}$-fixing bacteria. In addition, Azotobacter sp. that were clumped with S. oneidensis (labeled with arrows) were hard to confirm their presence based on the photomicrographic image (Figure 3a), but can be conclusively identified to be Azotobacter sp. based on the red spot in the Raman image, demonstrating the potential of Raman imaging in locating $\mathrm{N}_{2}$-fixing cells in microbial communities.

\section{Probing and Raman imaging $\mathbf{N}_{2}$-fixing bacteria of different activities in soil}

\section{communities}

We further applied ${ }^{15} \mathrm{~N}_{2}$ incubation and Raman imaging to reveal $\mathrm{N}_{2}$-fixing bacteria in soil microbial communities. Soils harbor a multitude of our Earth's biodiversity and also a high diversity of $\mathrm{N}_{2}$-fixing bacteria in either free form or in symbiosis with plants, ${ }^{46}$ representing the main site wherein biological $\mathrm{N}_{2}$ fixation is 
naturally carried out. Herein, park soil was collected from a grassland that had been left fallow for a long period of time without application of fertilizer, providing a high probability of detecting $\mathrm{N}_{2}$-fixing bacteria. Soil was placed in $12-\mathrm{ml}$ vials filled with a mixture gas of ${ }^{15} \mathrm{~N}_{2}\left({ }^{15} \mathrm{~N} 99.36 \%\right)$ and $\mathrm{O}_{2}$ at volume ratio of 4:1. After a 12-day incubation, the soil samples were collected. To date, application of Raman spectroscopy for single-cell investigations in soil systems has been very limited, ${ }^{17}$ because soil microorganisms are dispersed in a high background of soil particles. Separation of bacteria from soil particles is a necessity for either Raman or SIMS measurement. ${ }^{17}$ Soil bacteria were detached from soil particles via gradient density centrifugation reported previously. ${ }^{17}$ High-background soil particles can be largely reduced for both Raman and SIMS measurement. Figure 4 shows representative Raman spectra of individual soil bacteria with different phenotypes, including $\mathrm{N}_{2}$-fixing bacteria identified by $1114 \mathrm{~cm}^{-1}\left(\mathrm{C}-{ }^{15} \mathrm{~N}\right)$ band (i), bacteria containing Cyt $\mathrm{c}$ but unable to fix $\mathrm{N}_{2}$ (ii), bacteria containing Cyt $\mathrm{c}$ and carotenoid of different contents but unable to fix $\mathrm{N}_{2}$ (iii, iv), as well as bacteria without any pigments (v). The above finding indicates a high diversity of bacteria with different phenotypes in soil.

Raman imaging was then applied to soil bacteria to discern and image $\mathrm{N}_{2}$-fixing bacteria. Seven areas ranging from $20 \times 20$ to $30 \times 30 \mu \mathrm{m}^{2}$ were mapped. Because of the high diversity of soil bacteria, not every area contained both $\mathrm{N}_{2}$-fixer and non- $\mathrm{N}_{2}$ fixer. Two areas containing both were shown in Figure 5. The photomicrograph (Figure 5a, 5b left) shows soil bacteria of different shapes and sizes, but provides no information on function. In contrast, we can use spectral profile covering $1114 \mathrm{~cm}^{-1}$ and $1129 \mathrm{~cm}^{-1}$ band (Figure $5 \mathrm{c}$ red and green) to discriminate $\mathrm{N}_{2}$-fixing bacteria from non- $\mathrm{N}_{2}$-fixing bacteria. The resulting Raman images clearly reveal that the red 
393 dots are $\mathrm{N}_{2}$-fixing bacteria (labelled as ${ }^{15} \mathrm{~N}$ ), and the green dots are non- $\mathrm{N}_{2}$-fixing 394 bacteria containing Cyt c (Figure 5a, 5b right). Encircled bacteria (labeled with 'no 395 Cyt c' in Figure 5a) do not exhibit any pigment signal (Figure 5c, bottom curve 396 labeled with 'no Cyt c') and thus appear as a dark point in the Raman image. Figure $3975 \mathrm{~b}$ shows photomicrographic and Raman images taken from another independent 398 location. A total of six $\mathrm{N}_{2}$-fixing bacteria were discerned in the two areas, including 399 two (labelled as ${ }^{15} \mathrm{~N}-2$ and ${ }^{15} \mathrm{~N}-3$ ) in close contact with non- $\mathrm{N}_{2}$-fixing bacteria. The 400 green irregular shape connected with the ${ }^{15} \mathrm{~N}-2$ red dot shows good consistency with 401 the photomicrographic image, indicating a sufficient spatial resolution in Raman 402 images. These observations demonstrate that Raman images can discern $\mathrm{N}_{2}$-fixing 403 bacteria from soil communities based on their isotopic composition.

$404{ }^{15} \mathrm{~N}_{2}$-fixation extent by soil bacteria was also revealed based on spectral profile of 405 C- ${ }^{15} \mathrm{~N}$ and $\mathrm{C}-{ }^{14} \mathrm{~N}$ bands. Single-cell Raman spectra from a total of 29 individual 406 $\mathrm{N}_{2}$-fixing soil bacteria including the six identified above were incorporated together with the spectra of Azotobacter sp. incubated with different percentages of ${ }^{15} \mathrm{~N}_{2}$ (Figure 2c). As a comparison, three Raman spectra from soil bacteria similar to Azotobacter sp. incubated with $0.36 \%{ }^{15} \mathrm{~N}_{2}$ were also incorporated; this clearly indicates the presence of non- or weak $\mathrm{N}_{2}$-fixing bacteria in soil. PCA was then performed on spectra of $\mathrm{N}_{2}$-fixer and non or weak $\mathrm{N}_{2}$-fixer from soil to generate 1-D PCA scores (on the right of Figure 2c labeled as 'soil bacteria'). A larger variation in PC1 scores was observed in soil bacteria than Azotobacter sp. incubated with the same $99.36 \%{ }^{15} \mathrm{~N}_{2}$, indicating heterogeneous $\mathrm{N}_{2}$-fixing extent from diverse soil bacteria. Based on the linear correlation between ${ }^{15} \mathrm{~N}$ content measured by IRMS and PC1 scores of Azotobacter sp. incubated with different atmospheric ${ }^{15} \mathrm{~N}_{2} \%$ (Figure 2e), ${ }^{15} \mathrm{~N}$ content of soil bacteria were determined to be from 0 to 84.40 (on the right 
of Figure 2e) by inputting PC1 scores of soil bacteria to the linear fitting equation of ${ }^{15} \mathrm{~N} \%$ in cells $=38.79+75.18 \times \mathrm{PC} 1$. The even larger ${ }^{15} \mathrm{~N}$ incorporation extent in most $\mathrm{N}_{2}$-fixing soil bacteria than Azotobacter sp. should be related to the much longer incubation time of soil with ${ }^{15} \mathrm{~N}_{2}$ (12 days) than Azotobacter sp. (2 days).

\section{CONCLUSIONS}

This is the first demonstration that single-cell resonance Raman spectroscopy with ${ }^{15} \mathrm{~N}_{2}$-SIP can discern, image and compare the extent of $\mathrm{N}_{2}$-fixation of diverse $\mathrm{N}_{2}$-fixing bacteria in complex soil communities in a culture-independent fashion. Cyt $\mathrm{c}$ was demonstrated as a universal $\mathrm{N}_{2}$-fixation biomarker by investigating both model and environmental strains screened from soils. Its strong resonance Raman signal, together with a remarkable ${ }^{15} \mathrm{~N}$-induced $\mathrm{C}-\mathrm{N}$ band shifts of Cyt c, provided a robust biomarker to distinguish $\mathrm{N}_{2}$-fixing bacteria from non- $\mathrm{N}_{2}$-fixing bacteria with or without Cyt c. Raman imaging at micrometer resolution facilitated the location of $\mathrm{N}_{2}$-fixing bacteria in both artificial and soil communities. The linear correlation of C-N band profile with ${ }^{15} \mathrm{~N}_{2}$ percentages allowed a quantitative evaluation of $\mathrm{N}_{2}$ fixation extent of diverse soil bacteria.

For future work, this single-cell resonance Raman- ${ }^{15} \mathrm{~N}_{2}$ SIP approach can be applied to important $\mathrm{N}_{2}$-fixing symbiont systems. The further combination with single-cell isolation and genome sequencing suitable for soil microorganisms will also be developed, in order to reveal the precise ecological role of largely unexplored uncultured diazotrophs (microbial dark matter) in diverse ecosystems.

\section{References:}

(1) Hoffman, B. M.; Lukoyanov, D.; Yang, Z. Y.; Dean, D. R.; Seefeldt, L. C. Chem Rev 2014, 114, 4041-4062. 
(2) Cui, S. H.; Shi, Y. L.; Groffman, P. M.; Schlesinger, W. H.; Zhu, Y. G. Proc. Natl. Acad. Sci. U. S. A. 2013, 110, 2052-2057.

(3) Zehr, J. P.; Carpenter, E. J.; Villareal, T. A. Trends Microbiol. 2000, 8, 68-73.

(4) Shashar, N.; Cohen, Y.; Loya, Y.; Sar, N. Mar Ecol Prog Ser 1994, 111, 259-264.

447

(5) Rai, A. N.; Soderback, E.; Bergman, B. New Phytol. 2000, 147, 449-481.

(6) Lechene, C. P.; Luyten, Y.; McMahon, G.; Distel, D. L. Science 2007, 317, 1563-1566.

449

(7) Tai, V.; Carpenter, K. J.; Weber, P. K.; Nalepa, C. A.; Perlman, S. J.; Keeling, P. J. Appl. Environ.

450

451

452

453

454

455

456

457

458

459

460

461

462

463

464

465

466

467

468

469

470

471

472

473

474

475

476

477

478

479

480

481

482

483

484

485

486

Microbiol. 2016, 82, 4682-4695.

(8) Ohkuma, M.; Noda, S.; Hattori, S.; lida, T.; Yuki, M.; Starns, D.; Inoue, J.; Darby, A. C.; Hongoh, Y. Proc. Natl. Acad. Sci. U. S. A. 2015, 112, 10224-10230.

(9) Konig, S.; Gros, O.; Heiden, S. E.; Hinzke, T.; Thurmer, A.; Poehlein, A.; Meyer, S.; Vatin, M.; Mbeguie-A-Mbeguie, D.; Tocny, J.; Ponnudurai, R.; Daniel, R.; Becher, D.; Schweder, T.; Markert, S. Nat Microbiol 2016, 2, 16193

(10) Woebken, D.; Burow, L. C.; Prufert-Bebout, L.; Bebout, B. M.; Hoehler, T. M.; Pett-Ridge, J.; Spormann, A. M.; Weber, P. K.; Singer, S. W. ISME J. 2012, 6, 1427-1439.

(11) Sohm, J. A.; Webb, E. A.; Capone, D. G. Nat. Rev. Microbiol. 2011, 9, 499-508.

(12) Woebken, D.; Burow, L. C.; Behnam, F.; Mayali, X.; Schintlmeister, A.; Fleming, E. D.; Prufert-Bebout, L.; Singer, S. W.; Corte's, A. L. p.; Hoehler, T. M.; Pett-Ridge, J.; Spormann, A. M.; Wagner, M.; Weber, P. K.; Bebout, B. M. ISME J. 2015, 9, 485-496.

(13) Severin, I.; Stal, L. J. FEMS Microbiol Ecol 2010, 73, 55-67.

(14) Soares, R. A.; Roesch, L. F. W.; Zanatta, G.; Camargo, F. A. D.; Passaglia, L. M. P. App/ Soil Ecol 2006, 33, 221-234.

(15) Chalk, P. M.; He, J.-Z.; Peoples, M. B.; Chen, D. Soil Biol. Biochem. 2017, 106, 36-50.

(16) Roey Angel; Christopher Panhölzl; Raphael Gabriel; Craig Herbold; Wolfgang Wanek; Andreas Richter; Stephanie A. Eichorst; Woebken, D. Environ. Microbiol. 2018, 20, 44-61.

(17) Eichorst, S. A.; Strasser, F.; Woyke, T.; SchintImeister, A.; Wagner, M.; Woebken, D. FEMS Microbiol. Ecol. 2015, 91, fiv106.

(18) Martinez-Perez, C.; Mohr, W.; Loscher, C. R.; Dekaezemacker, J.; Littmann, S.; Yilmaz, P.; Lehnen, N.; Fuchs, B. M.; Lavik, G.; Schmitz, R. A.; LaRoche, J.; Kuypers, M. M. Nat Microbio/ 2016, 1, 16163

(19) Wang, Y.; Huang, W. E.; Cui, L.; Wagner, M. Curr. Opin. Biotechnol. 2016, 41, 34-42.

(20) Huang, W. E.; Griffiths, R. I.; Thompson, I. P.; Bailey, M. J.; Whiteley, A. S. Anal. Chem. 2004, 76, 4452-4458.

(21) Patzold, R.; Keuntje, M.; Theophile, K.; Muller, J.; Mielcarek, E.; Ngezahayo, A.; Ahlften, A. A. V. J. Microbiol. Methods 2008, 72, 241-248.

(22) Millo, D.; Harnisch, F.; Patil, S. A.; Ly, H. K.; Schroder, U.; Hildebrandt, P. Angew. Chem. Int. Edit. 2011, 50, 2625-2627.

(23) Virdis, B.; Harnisch, F.; Batstone, D. J.; Rabaey, K.; Donose, B. C. Energ Environ Sci 2012, 5, 7017-7024.

(24) Kubryk, P.; Kolschbach, J. S.; Marozava, S.; Lueders, T.; Meckenstock, R. U.; Niessner, R.; Ivleva, N. P. Anal. Chem. 2015, 87, 6622-6630.

(25) N., V. K. B.; Kampe, B.; Röschab, P.; Popp, J. Analyst 2015, 140, 4584-4593.

(26) Li, M. Q.; Canniffe, D. P.; Jackson, P. J.; Davison, P. A.; FitzGerald, S.; Dickman, M. J.; Burgess, J. G.; Hunter, C. N.; Huang, W. E. ISME J. 2012, 6, 875-885.

(27) Lutz, M. J. Raman Spectrosc. 1974, 2, 497-516. 
(28) Berry, D.; Mader, E.; Lee, T. K.; Woebken, D.; Wang, Y.; Zhu, D.; Palatinszky, M.; Schintimeister, A.; Schmid, M. C.; Hanson, B. T.; Shterzer, N.; Mizrahi, I.; Rauch, I.; Decker, T.; Bocklitz, T.; Popp, J.; Gibson, C. M.; Fowler, P. W.; Huang, W. E.; Wagner, M. Proc. Natl. Acad. Sci. U. S. A. 2015, 112, E194-E203.

(29) Huang, W. E.; Stoecker, K.; Griffiths, R.; Newbold, L.; Daims, H.; Whiteley, A. S.; Wagner, M. Environ. Microbiol. 2007, 9, 1878-1889.

(30) Muhamadali, H.; Chisanga, M.; Subaihi, A.; Goodacre, R. Anal. Chem. 2015, 87, 4578-4586.

(31) Cui, L.; Yang, K.; Zhou, G.; Huang, W. E.; Zhu, Y. G. Anal. Chem. 2017, 89, 5793-5800.

(32) Mariotti, A. Nature 1983, 303, 685-687.

(33) Burmolle, M.; Hansen, L. H.; Oregaard, G.; Sorensen, S. J. Microb Ecol 2003, 45, 226-236.

(34) Cui, L.; Butler, H. J.; Martin-Hirsch, P. L.; Martin, F. L. Anal Methods-Uk 2016, 8, 481-487.

(35) Cui, L.; Zhang, Y.-J.; Huang, W. E.; Zhang, B.-F. M., Francis L; Li, J.-Y.; Zhang, K.-S.; Zhu, Y.-G. Anal. Chem. 2016, 88, 3164-3170.

(36) Zhang, B.; Cui, L.; Zhang, K. Anal Bioanal Chem 2016, 408, 3853-3865.

(37) Luo, T.; Ou-Yang, X. Q.; Yang, L. T.; Li, Y. R.; Song, X. P.; Zhang, G. M.; Gao, Y. J.; Duan, W. X.; An, Q. J. Basic Microbiol. 2016, 56, 934-940.

(38) Feng, C.; Li, J.; Qin, D.; Chen, L.; Zhao, F.; Chen, S.; Hu, H.; Yu, C. P. Plos One 2014, 9, e113379.

(39) Strekas, T. C.; Spiro, T. G. Biochim. Biophys. Acta 1972, 278, 188-192.

(40) Xu, J.; Webb, I.; Poole, P.; Huang, W. E. Anal. Chem. 2017, 89, 6336-6340.

(41) Poole, R. K.; Hill, S. Biosci. Rep. 1997, 17, 303-317.

(42) Droghetti, E.; Oellerich, S.; Hildebrandt, P.; Smulevich, G. Biophys. J. 2006, 91, 3022-3031.

(43) Hu, S. Z.; Morris, I. K.; Singh, J. P.; Smith, K. M.; Spiro, T. G. J. Am. Chem. Soc. 1993, 115, 12446-12458.

(44) Jochum, T.; Fastnacht, A.; Trumbore, S. E.; Popp, J.; Frosch, T. Anal. Chem. 2017, 89, 1117-1122.

(45) Keiner, R.; Herrmann, M.; Kusel, K.; Popp, J.; Frosch, T. Anal. Chim. Acta 2015, 864, 39-47.

(46) Paul, E. A. Soil Microbiology, Ecology and Biochemistry; Academic Press: Boston, 2014.

Supporting Information Available: Experimental description of 16s rRNA and nifH gene sequencing. Phylogenic trees. Deconvolution of Raman band and correlation of band area ratio with ${ }^{15} \mathrm{~N}_{2}$ percentage. Raman spectra of other types of $\mathrm{N}_{2}$-fixing bacteria and related bacteria.

\section{Author information}

Corresponding Author

*E-mail, ygzhu@ @rcees.ac.cn. Phone: 86-5926190997.

The authors declare no competing financial interest.

\section{Acknowledgements}


523 This work was supported by National Key Research and Development Program of 524 China (2017YFD0200201, 2017YFE0107300), the Strategic Priority Research 525 Program of Chinese Academy of Sciences (XDB15020302, XDB15020402), Natural 526 Science Foundation of China (21777154) and K.C.Wong Education Foundation.

527

528

529

530

531

532

533

534

535

536

537

538

539

540

541

542

543

544

545 
546

547

548

549

550

551

552

553

554

555

556

557

558

559

560

561

562

563

\section{Figure legends}

Figure 1. Gel image of PCR product of nifH genes specific for $\mathrm{N}_{2}$ fixation (a) and single-cell resonance Raman spectra (b) from $\mathrm{N}_{2}$-fixing bacteria isolated from soil (red), model $\mathrm{N}_{2}$-fixing bacteria (blue), non $\mathrm{N}_{2}$-fixing $S$. oneidensis and E. coli (black). 'No template control' in gel image is the negative control without DNA template for PCR.

Figure 2. (a) Single-cell resonance Raman spectra of Azotobacter sp. incubated with ${ }^{15} \mathrm{~N}_{2}$ of $99.36 \%, 49.68 \%, 25.02 \%, 10.22 \%, 0.36 \%$ relative to $\mathrm{N}_{2}$ in air. (b) Spectral region including exclusively $1114 \mathrm{~cm}^{-1}\left(\mathrm{C}^{-15} \mathrm{~N}\right)$ and $1129 \mathrm{~cm}^{-1}\left(\mathrm{C}-{ }^{14} \mathrm{~N}\right)$ bands extracted from a. (c) Correlation between incubation ${ }^{15} \mathrm{~N}_{2}$ percentage versus ${ }^{15} \mathrm{~N}$-induced spectral changes in single cell based on PCA 1-D scores. Each point is a measurement of a single cell, and around 25 cells were measured. (d) Quantification of bulk ${ }^{15} \mathrm{~N}$ content in Azobacter sp. from the same incubation as in Raman as detected by isotope ratio mass spectroscopy. ${ }^{15} \mathrm{~N}$ abundance in $E$. coli and $S$. oneidensis incubated with $99.36 \% \mathrm{~N}_{2}$ was also shown. (e) Correlation between ${ }^{15} \mathrm{~N}$ content of Azobacter sp (from d) and PC1 scores (from c). Data points on the right of c and d labeled as soil bacteria were from active $\mathrm{N}_{2}$-fixing and non or weak $\mathrm{N}_{2}$-fixing soil bacteria.

Figure 3. (a) Photomicrograph of a mixed artificial community containing $\mathrm{N}_{2}$-fixing Azotobacter sp. incubated with ${ }^{15} \mathrm{~N}_{2}$ in $\mathrm{N}$-free medium and non- $\mathrm{N}_{2}$-fixing $S$. oneidensis grown in LB medium - two images showing the different shapes (isospherical vs. rod-shaped) of these two bacteria are shown below. (b) 
568

569

570

571

572

573

574

575

576

577

578

579

580

581

582

583

584

585

586

587

588

589

Corresponding Raman image from the same area as in a. (c) Typical Raman spectra acquired from Azotobacter sp. and S. oneidensis in a and b. Bands at $1114 \mathrm{~cm}^{-1}$ $\left(\mathrm{C}-{ }^{15} \mathrm{~N}\right)$ and $1129 \mathrm{~cm}^{-1}\left(\mathrm{C}-{ }^{14} \mathrm{~N}\right)$, representing ${ }^{15} \mathrm{~N}_{2}$-fixing (red) and non- $\mathrm{N}_{2}$-fixing bacteria (green), were employed to construct the Raman image.

Figure 4. Single-cell Raman spectra of diverse soil bacteria extracted from soil after 12-day incubation with ${ }^{15} \mathrm{~N}_{2}$. Each spectrum represents a characteristic phenotype. i, $\mathrm{N}_{2}$-fixing bacteria; ii, bacteria containing Cyt $\mathrm{c}$ but unable to fix $\mathrm{N}_{2}$; iii and iv, bacteria containing both Cyt $\mathrm{c}$ and carotenoid but unable to fix $\mathrm{N}_{2}$; v, bacteria without any pigment.

Figure 5. (a, b) Photomicrograph (left) and Raman images (right) of bacteria extracted from soil microcosms incubated with ${ }^{15} \mathrm{~N}_{2}$ for 12 days. (c) Resonance Raman spectra of single cells from six $\mathrm{N}_{2}$-fixing bacteria $\left({ }^{15} \mathrm{~N}-1,2,3,4,5,6\right)$, non- $\mathrm{N}_{2}$-fixing bacteria $\left({ }^{14} \mathrm{~N}\right)$, and bacteria without Cyt c (no Cyt c) in a and b. Bands at $1114 \mathrm{~cm}^{-1}\left(\mathrm{C}^{-15} \mathrm{~N}\right)$ and $1129 \mathrm{~cm}^{-1}\left(\mathrm{C}-{ }^{14} \mathrm{~N}\right)$ were used to construct the Raman images exhibiting $\mathrm{N}_{2}$-fixing bacteria as red, non- $\mathrm{N}_{2}$-fixing bacteria containing Cyt $\mathrm{c}$ as green, and bacteria without Cyt $\mathrm{c}$ as black.

.

(1) 
a
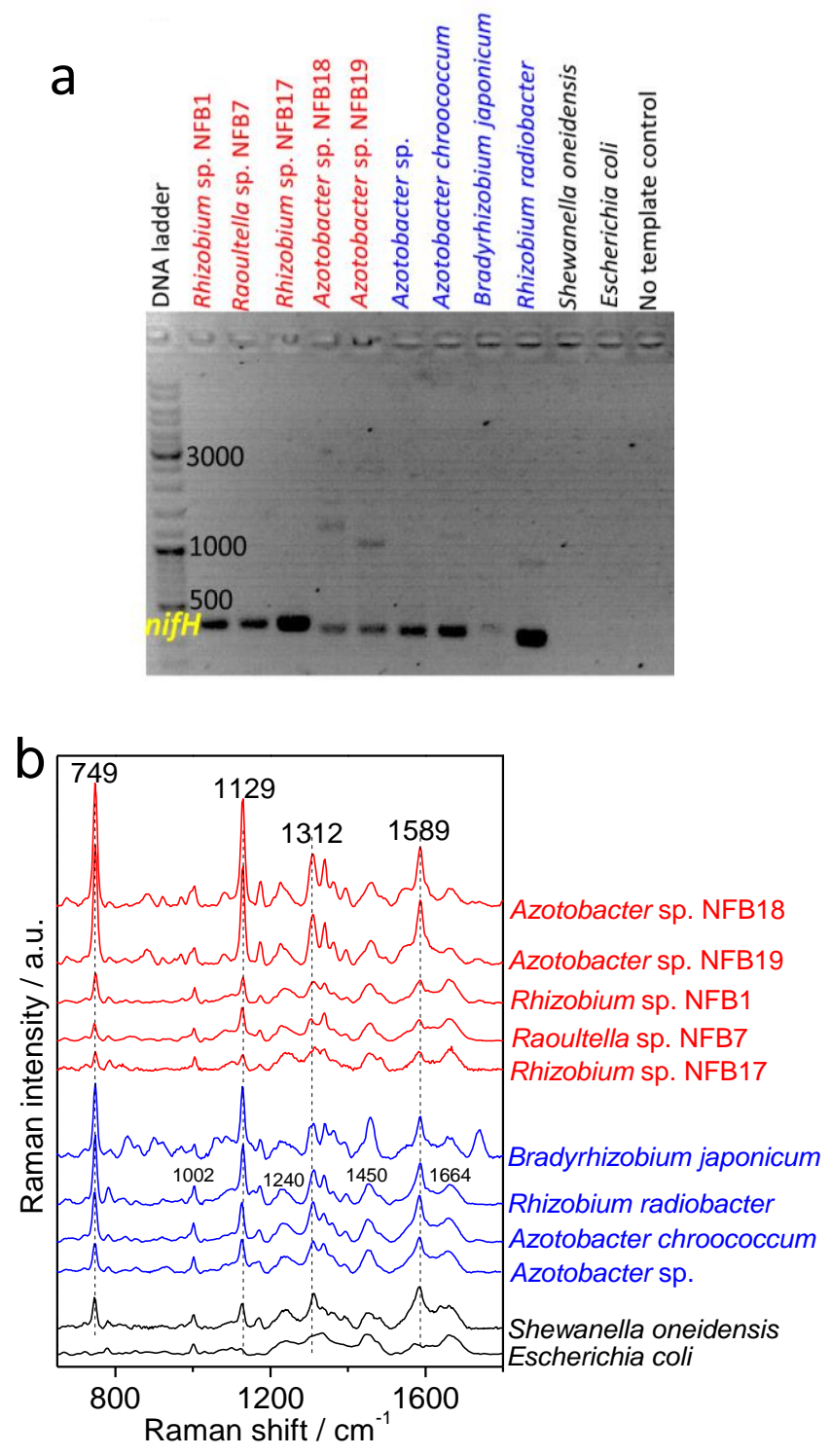


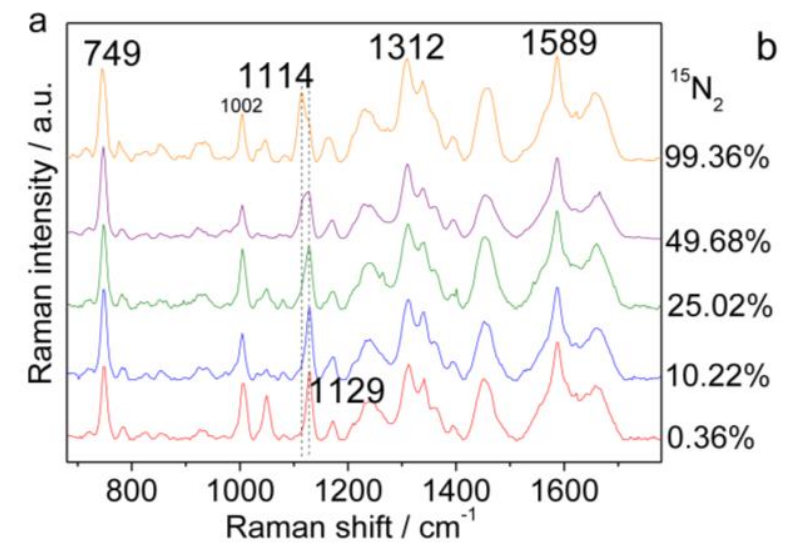

C

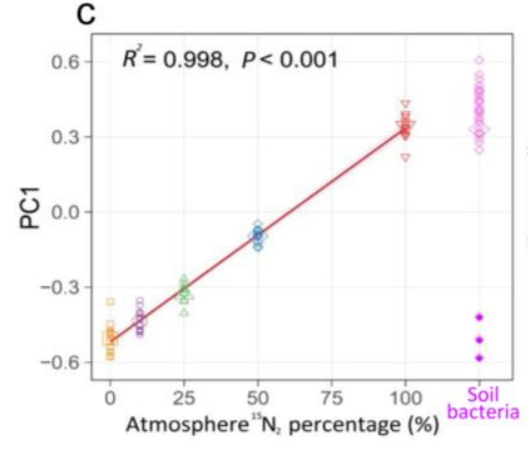

599

600

601

602

603

604

605

606

607

Figure 2
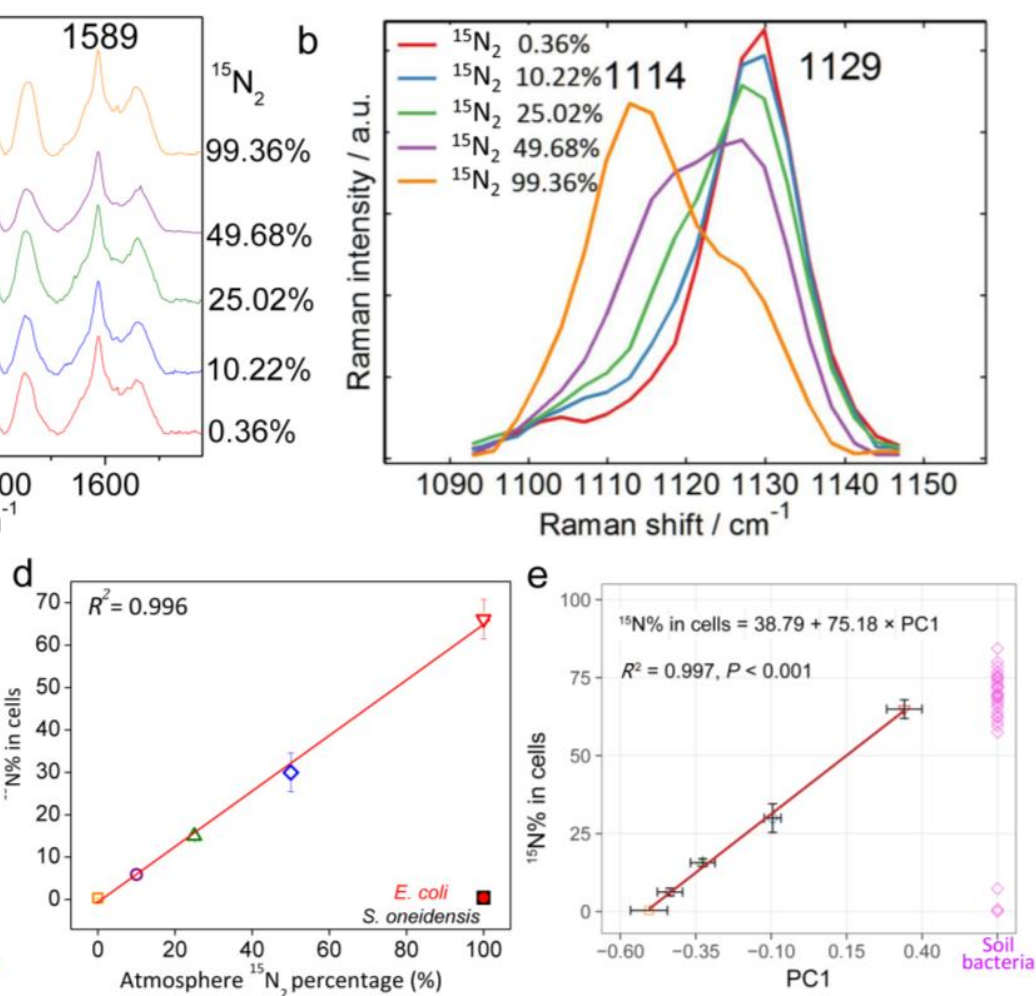

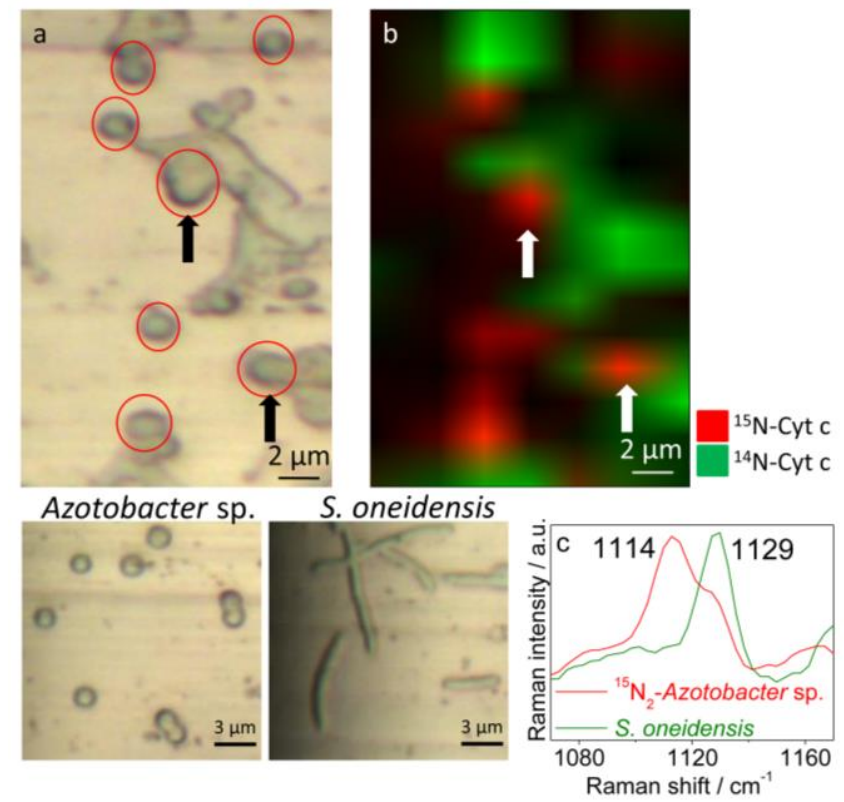

Figure 3

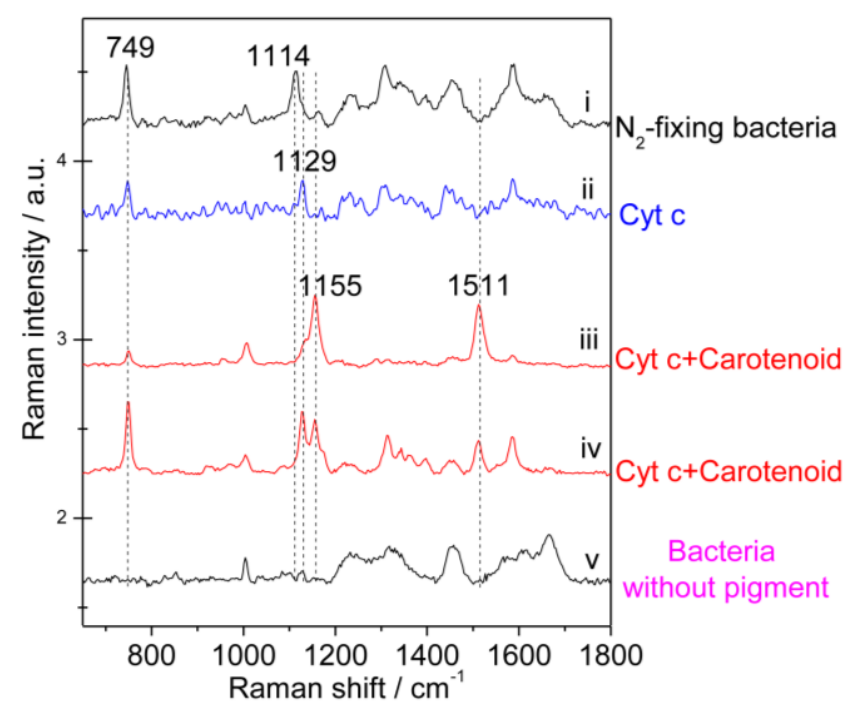

\section{Figure 4}



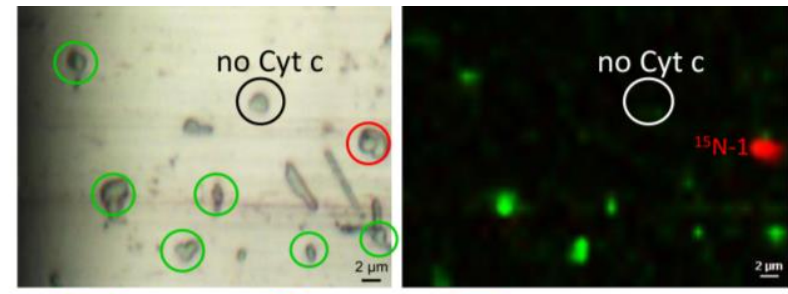

b
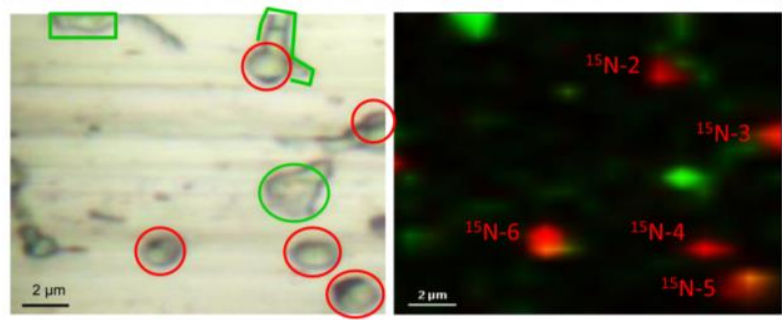

c

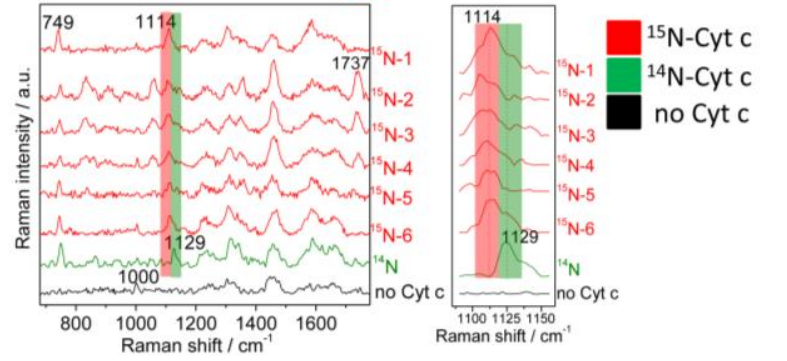

Figure 5 